grown from 2,622 million franes in 1960 to 4,690 million francs in 1964, 85 per cent of which is for the Departments of Education (58 per cent) and Economic Affairs (27 per cent), and, of this, 24.5 per cent and 26.5 per cent, respectively, are for research. Universities and institutions of higher education received 2,714 million francs; Government scientific establishments, 1,472 million francs; while 298 million francs went to the private sector.

Expenditure on fundamental research is estimated at 1,500 million franes and on applied research at 1,446 million franes. The Council recommends an annual growth of 15 per cent in the scientific budget as essential to provide normal development of higher education and research; grants for particular fields of science should be weighted within this limit.

The distribution of the scientific budget between different fields of science and institutions is analysed in some detail in the following chapter, which also discusses the reorganization of nuclear research and space research. The Government has accepted the Council's recommendation for the establishment of new university institutions at Anvers and Mons. The Council, after examining the work of the teaching hospitals, has recommended drawing a distinction between them and certain specialized and other university services and is now considering a general programme of development for the biological and medical services, having regard to the legal and social as well as the financial aspects. Some integration and regrouping of some of the scientific services and establishments of the State is also recommended and there is also a brief discussion of the status and organization of scientific staff in the Government service and in the State universities.

The 2,059 professionally qualified scientific staff, the 2,334 possessing technical diplomas and the 7,470 technicians and others engaged in scientific activitios in 1961 were employed in 1,377 institutions. Of these latter, 180 were concerned with chemistry, rubber or pharmacy, 58 with metallurgy, 435 with metal manufacture, and 176 with textiles; the corresponding figures for qualified scientific staff are $874,203,450$, and 73 , respectively; for technical staff, $791,219,755$ and 122 ; and for technicians, etc., $2,932,1,000,2,359$, and 238 . The corresponding distribution of the total expenditure of 2,882 million francs was 1,282 million francs, $235 \cdot 5$ million francs, 1,029 million francs, and 47 million francs, respectively. There is also a brief account of the activities of the National Foundation for the Finance of Scientific Research.

\title{
ASSESSMENT PROCEDURES IN SECONDARY SCHOOL SCIENCE
}

\begin{abstract}
T F. EGGLESTON holds a research fellowship in the . Sehool of Education, University of Leicester, where special thought is being given to the teaching of science in schools along with related questions of syllabuses and examinations. His paper* is mainly concerned with the examinations for the Certificate of Secondary Education, which in the past few years have been taken by an increasing number of boys and girls of Newsom quality, that is, those not normally expected to become sixth-form spocialists. His essay merits attention, for it amounts to an interim report on a problem which is entering on a period of rapid change, while with varying impact all examinations in science are subject to the same considerations.
\end{abstract}

As Eggleston points out, in the past, examinations have served a dual purpose, providing measurements of achievement and predictions for the future. Up to now the first of these aims has been predominant, with its emphasis on the factual content of the syllabus to the detriment of original enquiry and practical experience. In support of this contention he draws on a survey of examinations at 'O' level, by R. W. Crossland and R. Amos, recently published in Biology and Human Affairs $\dagger$.

The Boards which have been established to conduct examinations for the Certificate of Secondary Education have attempted to devise courses of work and tests to meet a wider range of requirements, as, for example, to make observations, develop manipulative skill, foster the ability to solve problems, and develop the pupils' ability to 'think scientifically'. Following R. L. Ebel and B. S. Bloom in America, and. J. Furst in England, Eggleston maintains that aims like these are much too general; to increase their validity they need to be defined in more precise terms. He also thinks that no count should be taken of pupils' interests and enthusiasms, partly because as attributes they are subjective, and also because in many cases they are ephemeral.

$\mathrm{He}$ does not deal with oral examinations, which raise problems of a different kind. As for practical tests, he holds that under favourable conditions they measure *A Critical Review of Assessment Procedures in Secondary School Science
(with Special Reference to C.S.E.). By J. F. Eggleston. Pp. 56. (School of Education, University of Leicester, 1965.) $5 s$.

$\dagger$ Crossland, R. W., and Amos, R., Biol. and II um. Affairs, 30, 35 (1965). qualities not disclosed by other procedures. Biology teachers appear to be most convinced of their validity, at the level of the Certificate of Secondary Education, although, owing to difficulties in arranging for them, some Boards do not make use of them at all. Similarly, a good case can be made for supplementary assessments based on course work, made by teachers who are in constant touch with their pupils, but again, subjective elements are involved. Altogether, in reading this essay, one is impressed by the number of questions which remain wide open, and by the spirit of amateurism which still prevails in a situation which urgently calls for hard scientific experiment and thought.

Even when some of these questions come nearer to solution, others of comparable import will remain. One, for example, is the advisability of holding any examinations at all at Certificate of Secondary Education level since they draw a line between the pupils who pass and the large number of children who fail to make the grade. Still, since this system is now in being it may call for modification rather than immediate abolition. Another question is the narrowing of interest and reduction in the teacher's initiative brought about by any examination syllabus; while a third, of similar classroom applicability, is that of the sophistication introduced by teachers who seek to anticipate examiners' requirements, as in questionspotting. This consideration produces moro distortion in the simpler kinds of tests.

Beyond the schoolroom other questions await attention. For example, scientific ability is protean in its diversity; it cannot be reduced to a tidy single entity; and most of the outstanding discoveries in science cut across current techniques and systems of reasoning, they cannot be prepared for by training in making observations, and the spirit of enquiry is not a kind of searchlight which can be switched on and off at will. Scientists need time to brood, and their single-mindedness is something of spontaneous growth. How is it to be fostered? How is it to be assessed?

Then, no course in science can claim to be truly educational unless thought is given to its informational content, including appreciation of some of the major applications which provide the material fabric of our civilization; and at a higher level, all young people should be given some 
understanding of the part science plays in cultural life, including moral and even, perhaps, spiritual issues. In this sense the ideological content of syllabuses will have to be brought under review. Points liko these pose difficult questions for teachers and examiners, but if in their training young scientists are to be treated wholly as specialists they will remain nothing but specißlists when they grow up.

R. WeAtherati

\section{REPORT OF THE AGRICULTURAL RESEARCH COUNCIL 1963-65}

\begin{abstract}
T HE Report of the Agricultural Research Council for the years 1963-65 (Cmnd. 2792, H.M. Stationory Office, 8s.) describes tho work of twelve out of the forty. seven institutes and units for which the council is, in effect, responsible; summarizes sorno of the major developments in the two yeurs under review; and, in so doing, demonstrates tho wide range of modern agricultural research. Thus, in soils, work (some of which may be relevant to prablic health) on the persistence of organo-ehlorine insecticides shows that a single dressing of dieldrin has offectively controlled carrot fly, Psila rosae, for nine years, while very low residues of this compound reduced the natural enomios of the cabbage root fly, Erioischia brassicae, and thus aided the survival of this pest. If the placement of fertilizers at depths of up to $2.5 \mathrm{ft}$. can be made practicable, then sub-soil water could be more effectively used by pastures, and irrigation noods reduced.

In crops, the influence of kinins on root growth, gormination, bud growth and loaf-sonescence (which affects the effective photosynthetic area) is noted, while revolutionary possibilitios are opened up by complete chemical control of vegetation which permits 'minimal cultivation' and even brings into question the nceessity for ploughing.

In animals, resoarch on the metabolism of clinical disorders associated with calcium, phosphorus, iron, copper, magnesium, zine and solenium illustrates the biochemical comploxities of intensive animal production, while work at tho Animal Diseases Research Association in Seotland on that elusive disense of shoep, scrapie, oxemplifies the value of multi-discipline researeh. A link
\end{abstract}

between reproduction research in humans and livestock is seen in the uso, on pigs, of a temporary ovulation inhibitor which opens up tho prospect of synchronizex 'batch farrowing' by pig producers.

The Council (which now reports to the Department of Education and Science) is, of course, primarily concorned with scientific and engineering rosoarch. This may explain why there is no mention of the tentative, but potentially very important, link betwoon scientific and farm management research through the croation, by multi-variable experiments, of the muli-dimensional input-output curves so badly neoded for the effective application to farming of modern business mathomatics.

The roport concludes with administrative and financial data. The total spent each year by or on behalf of the Council is about $£ 10$ million in Great Britain. This oxcludes research at official husbandry farms, on farm management, by agricultural economists, by the official veterinary service, by the supporting chemical and ongineering industries and by agricultural scientists at univorsities. Even if this group spent as much as the Agricultural Research Council, the total resoarch expenditure on and in the agricultural industry would only be about 1 per cent of the value of its gross annual sales. In farming in the United Kingdom, productivity per man is increasing at about 7 per cent per annum-one of the highest rates in the national cconomy. What further contribution could agriculture make to national conomic efficiency if rosearch expenditure was doubled? A. N. Duckнaм

\section{ANTIMICROBIAL AGENTS AND CHEMOTHERAPY}

$\mathrm{V}^{\mathrm{s}}$ ARIOUS aspects of antimicrobial agents, infectious diseases, and chemothorapy were discussed during October 17-21, 1965, in the 237 papers and 11 round tables and conferences presented at the fifth Interscionce Conference on Antimicrobial Agonts and ChemotherapyFourth International Congress for Chemotherapy. This moeting was held in Wushington, under the sponsorship of the American Society for Microbiology and the International Society for Chemotherapy, and was organized with the co-operation of the Infectious Diseases Society of America. 1,422 interestod scientists attended this meeting; 228, representing 26 countries, came from outside the United States.

The Congress opened with addresses by Prof. E. B. Chain, Prof. S. A. Waksman, and Prof. J. F. Enders, discussing the past 25 years of antibiotic therapy and prospects for the future. This theme of reviewing the accomplishment of the past and problems of the immediate future was carried further in a round table on "Are Now Antibioties Neoded ?" organized by Prof. M. Fintand. The consensus of the panol membors, including Profs. W. M. M. Kirby, H. F. Dowling, A. C. Todd and L. P. Garrod, and Prof. E. B. Chain, Dr. Y. Chabbert and Dr. C. W. Pettinga, was that new and specialized antibiotics are still needod. There aro many infections which are not adequately treated by tho availablo antimicrobial agents and there is a need for a 'good' antifungal agont, a better anti-Gram-nogativo bacterial agent, and agents to troat a host of 'uncovered diseases' including the viral diseases and those caused by protozoa and othor parasites. Other round tables wore concerned with "Gram-negative Infections", "Antibiotic Assay Mothods", "Bacterial Sonsitivity Testing Methods", and the "Chomothorapy of Venereal Diseasos". In each of these panel discussions, experts from many countries reviewed their findings in the particular subject being discussed, and presented now information on the prospocts for the immediate future. The need for non-toxic and effective antibioties in the treatmont of Gram-negative infections, the fungal infertions, and in venereal disoases was repeatedly emphasized.

Among the topics discussed at the 'informal discussions' were: practical methods for handling information on antibiotics and chemotherapy; the activities of the International Conter for Antibiotic Information (Liège); antibiotic nomenclature; and ecological roles of antibiotics. The following rules were proposed for choosing antibiotic names: (a) an antibiotic's name should be chosen so that, if it is later shown to be a momber of a family, the rootname can be modified to show members of tho related sories. (b) The name should be based on chemical structure, and, except where the structuro is known, the name should be based on the generic class of the producing organism. (c) The name chosen should be euphonious.

A symposium on the chemotherapy of tuberculosis (organized by Dr. G. Brouet, Paris) included discussion of experimental bases of chemotherapy (by Dr. F. Grumbach), therapoutic possibilities with minor antibacterial drugs in infections with Mycobacterium tuberculosis (Prof. 